\title{
Factors Affecting the Bank Credit Accessibility of Rural Households in Vietnam
}

\section{Tran Long Giang 1 Hoang Thi Thanh Hang ${ }^{2}$}

${ }_{1,2}$ Banking University of Ho Chi Minh City, Vietnam

'Email: giangtl.cth@vietcombank.com.vn Tel: (+84)909979899

'Email:hanghtt@buh.edu.vn Tel: (+84)933535455

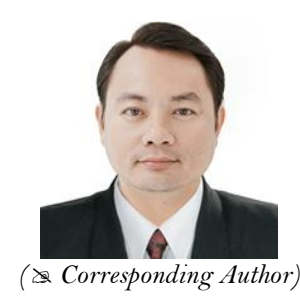

Abstract

The research identifies and measures factors affecting the bank credit accessibility using Heckman (1979). The research uses data from dataset of Vietnam Household Living Standard Survey (VHLSS) in 2014 and 2016 to eliminate the shock due to the global economic crisis in 2008-2009 making the estimate unsustainable. The results show that among the factors that can affect the bank credit accessibility considered in the first stage of Heckman model, there are six factors that significantly and statistically affect the bank credit accessibility of rural households. These factors include the household's average income, householder's age, ethnic group, marital status, previous loan period and members of the Farmers Associations. The estimate results obtained from the second stage of Heckman model on the possibility to receive loans of rural households in Vietnam indicates seven factors affecting the value of loans received from bank credit institutions are the household's average income, householder's age, ethnic group, marital status, previous loan period and members of the Farmers Associations.

Keywords: Credit accessibility, rural households, loan, banks

Citation | Tran Long Giang; Hoang Thi Thanh Hang (2019). Factors Affecting the Bank Credit Accessibility of Rural Households in Vietnam. Asian Journal of Economics and Empirical Research, 6(1): 59-69.

History:

Received: 24 December 2018

Revised: 29 January 2019

Accepted: 4 March 2019

Published: 20 May 2019

Licensed: This work is licensed under a Creative Commons

Attribution 3.0 License $(\mathrm{ccc}) \mathbf{E}$

Publisher: Asian Online Journal Publishing Group
Contribution/Acknowledgement: Both authors contributed to the conception and design of the study.

Funding: This study received no specific financial support.

Competing Interests: The authors declare that they have no conflict of interests.

Transparency: The authors confirm that the manuscript is an honest, Transparency: The authors confirm that the manuscript is an honest,
accurate, and transparent account of the study was reported; that no vital accurate, and transparent account of the study was reported; that no vital
features of the study have been omitted; and that any discrepancies from the study as planned have been explained.

Ethical: This study follows all ethical practices during writing.

\section{Contents}

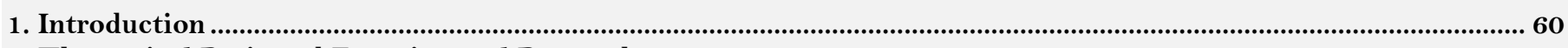

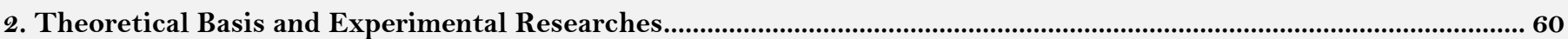

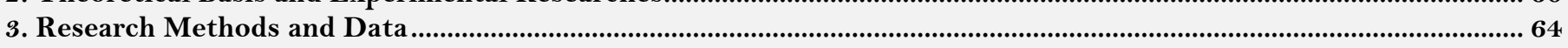

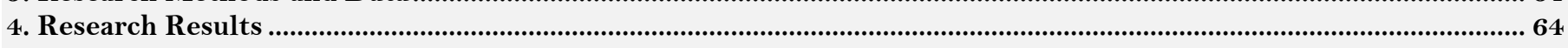

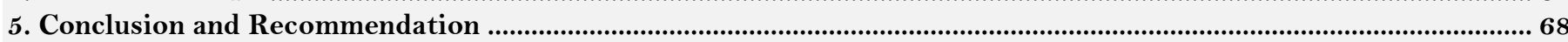

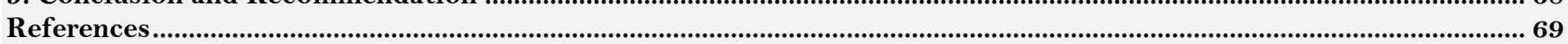




\section{Introduction}

According to the Report of the General Statistics Office in 2016, the proportion of people living in rural areas of Vietnam accounts for about $68 \%$, equivalent to 61.2 million people. Therefore, the rural issues are particularly paid attention in Vietnam in recent years. However, rural households face many difficulties in accessing bank credits.

Currently, there are several researches on the factors affecting the credit accessibility with different methods, times of research and scopes of research. Some of them show that the householder's educational level, income, purpose of borrowing, land area and collaterals affect the credit accessibility of rural households (Nguyen and Pham, 2010). Others state that organizations and unions such as Farmers Associations and Women's Unions play an important role in the credit accessibility of rural households in Vietnam, Economic and Development Group (2010).

In this research, the selected times of research are 2014 and 2016 and a scale of samples include 598 households in 61 provinces/cities to eliminate the shock caused by the economic crisis in 2008 affecting the sustainability of estimated coefficients. Therefore, identification and measurement of the factors affecting the bank credit accessibility and proposal thereon of implications for the bank credit accessibility are necessary.

\section{Theoretical Basis and Experimental Researches}

\subsection{Theoretical Basis}

\subsubsection{Asymmetric Information and the Opposite Choice}

According to the most basic economic theory that is market equilibrium, in which if demand exceeds supply, the price will rise and vice versa. Decrease of demand and/or increase of supply should be made until supply and demand equal a new equilibrium price. Therefore, credit supply and demand decisions depend on interest rates. However, according to Stiglitz and Weiss (1981) the theory of interest rate-based credit supply and demand cannot explain the behavior of lenders and borrowers since the borrowers do not rely on market interest rates only while lenders must depend on the borrowers' information to make loan decisions.

According to Stiglitz and Weiss (1981) for credit markets, opposite option is also a consequence of asymmetric information, which means potential borrowers with more risks often seek loans and have rights to select, in which the distinction between low-risk and high-risk borrowers is reflected in interest rates. However, raising interest rates to compensate for high credit risk costs may push low-risk borrowers out of the market. As a result, lenders approve the high-risk projects only. Asymmetric information also leads to moral hazards or dependence, in which borrowers are no longer motivated to try or act as reasonably as before the occurrence of transactions as lenders must suffer a part of risks. Consequently, borrowers cannot pay their debts. In general, decisions on credit issue and credit amount depend on the information obtained by lenders from borrowers. Thus, not all people wishing to borrow can access to credit.

\subsubsection{Factors Affecting the Credit Accessibility}

In the countries with underdeveloped financial systems, poor households have more limited credit accessibility than the wealthy ones. According to Claessens and Feijen (2007) there are three main causes that hinder the credit accessibility of poor households: The generally unstable institutional and economic environment; Unsuitable supply and demand; the influence of special benefits, according to Rajan and Zingales (2003).

Recently, accessibility to financial services is recognized as an important aspect of development. Increasing the accessibility to finance requires the efforts of the government and financial institutions. Based on that, Claessens and Feijen (2007) proposed nine policy recommendations: Increase the scale of financial institutions and the financial system in general to benefit from economies through scale; Use existing networks to expand the scope of access; Improve credit infrastructure; Minimize as much as possible the government regulation; Enhance competition in the financial system; Promote comprehensive access to financial services; Introduce products creatively and in the best practices to meet customer needs; Collect data and expand scope; Conduct further researches and analysis of financial access.

\subsection{Experimental Researches}

\subsubsection{Researches in the World}

Ololade and Olagunju (2013) analyzed the factors affecting the credit accessibility of rural households in Oyo, Nigeria, using primary data through questionnaires collected from 210 observations. Based on descriptive statistics results and Logistic models, the research showed that gender, marital status, guarantee and high interest rate are important factors affecting the credit accessibility of rural households.

Mwangi and Sichei (2011) used a polynomial Probit model to look for factors affecting the credit accessibility of individuals residing in Kenya based on Kenya's National FinAccess Survey in 2006 and 2009. The results showed that the household size reduces the accessibility to loans from banks and Accumulated Savings and Credit Associations (ASCAs) but promotes borrowing from agricultural product buyers. The geographical distance between households and credit providers has a negative impact on the credit accessibility. In contrast, age, educational level and income are factors that increase the credit accessibility. In particular, age affects the credit accessibility in an inverted $U$ shape, which means that the closer age of retirement is, the more increasing the decrease of accessibility is.

Kiplimo et al. (2015) determined the factors affecting the credit accessibility of rural households in Kenya. Logistic regression results indicated that the factors including educational level, occupation and access to agricultural extension services have a positive and statistical significant impact on the credit accessibility. However, the total income of a household and the geographical distance between such household and the credit provider have a negative impact on the credit accessibility. 


\subsubsection{Researches in Vietnam}

In Vietnam, there have been some researches on factors affecting the credit accessibility in different research periods and scopes of research. Nevertheless, the research results are not highly consensus among each other.

+ The research carried out by Nguyen and Pham (2010) investigating factors affecting the formal credit accessibility of rural households nearly Hanoi suburbs showed that age and social status of householder, informal credit and loan procedures are important factors affecting the formal credit accessibility of rural households here. At the same time, it indicated that the borrowed credit capital is affected by factors such as educational level of the householder, household income, purpose of borrowing, land area and collaterals.

+ The Development Economics Research Group (DERG) used Heckman's sample selection model and instrumental variable estimation (IVE) based on the data from Survey of Accessibility to resources of Vietnamese households in 2006, 2008 and 2010. The results showed that the credit accessibility in Vietnamese rural areas is not subject to many credit barriers. It is evidenced by that the difference among characteristics of the households without credits and households with credits is negligible in aspects of income, educational level, marital status, ethnic group and land property. In addition, organizations and unions such as the Farmers Associations and Women's Unions play an important role in the credit accessibility of Vietnamese rural households in relation to agricultural, non-agricultural and investment loans.

Nguyen (2007) analyzed factors affecting the credit accessibility and borrowing behavior in Vietnam's rural credit market in the period 1993-1998. By using Tobit, Probit and Heckman models, the research also proved that the credit accessibility in the rural areas is low. Evidence pointing out important factors affecting the credit accessibility of households are educational level, health conditions, fixed assets held and distance from the location where households are residing to the Bank branches.

Nguyen et al. (2016) studied factors affecting the formal credit accessibility of households raising black tiger shrimps in Cau Ngang district, Tra Vinh province. Through their descriptive statistical analysis, this research group pointed out that the purpose of formal credit borrowing by the households raising black tiger shrimps in the research location is to expand their production scale. Using the Tobit model based on primary data collected in September 2015 from 245 rural households with or without formal credit loans, evidence showed that shrimp raising area, interest, borrowing procedures, social position of households and the need to expand production scale are important factors affecting the loan amount issued to rural households raising black tiger shrimps in Cau Ngang district, Tra Vinh province. In particular, the shrimp raising area has the greatest impact on the loan amount issued to rural households raising black tiger shrimps.

Using Logistic and ordinary least square (OLS) regression models, Tran and Huynh (2013) analyzed factors affecting the formal credit accessibility of rural households in An Giang province. The research used primary data through random surveys and interviews with 150 households in December 2010 in 3 districts of An Giang province including Chau Phu, Phu Tan and Cho Moi. The results explained that the percentage of households approved to borrow is $24 \%$ less than the credit demand or limit. Based on the Logistic model estimation analysis, the probability of credit limit of rural households is affected by some factors including (i) educational level; (ii) occupation of the householder; (iii) residential land area; (iv) asset value of household; (v) use of commercial credit. Additionally, the OLS multivariate regression analysis results reflected that the formal credit capital is affected by the following factors: (i) social relations of the householder; (ii) purpose of borrowing; (iii) asset value; (iv) household income. Bui and Truong (2014) investigated the formal credit capital accessibility of households raising shrimps based on primary data collected from 242 households through interviews in 10 communes of 3 districts that have large shrimp raising areas in Tra Vinh province. Evidence indicated that 5 factors positively impacting on the formal credit capital accessibility of households raising shrimps are (i) household income; (ii) occupational duration (production experience); (iii) loan interest rate of the household; (iv) number of borrowing transactions with credit institutions of the household; (v) number of local credit institutions. On the other hand, the distance from the place where the household is residing to the district center is considered as a negative factor affecting the formal credit capital accessibility of households raising shrimps in Tra Vinh province.

To identify the factors affecting the formal credit capital accessibility of households raising pigs in $\mathrm{O}$ Mon District, Can Tho City, Vuong and Dang (2015) used the Probit regression model based on primary data through direct interviews with 223 households raising pigs in the research area. The research pointed out the factors that have a significant impact on the formal credit capital accessibility are: (i) gender of the householder; (ii) educational level of the householder; (iii) age of the householder; (iv) social position of the household; (v) household income.

Based on the primary data collected from 919 households through interviews, Phan (2013) analyzed the factors affecting the formal and informal credit accessibility of rural households in 13 provinces in the Mekong Delta. Using conditional mixed process (CMP) developed by Roodman (2009) Probit estimation, Tobit estimation and Heckman's two-stage regression models, the evidence showed that 3 factors having important influence to informal loans include land ownership, official interest rates and loan terms. For microcredit accessibility, 6 significant factors indicated from the research are: (i) employee working at local authorities; (ii) member of lending group; (iii) poor household book; (iv) educational level; (v) skilled labor; and (vi) inter-commune roads. Furthermore, the research also provided evidence of interaction among credit markets, in particular, the amount of informal credit loans has a positive impact on the accessibility to microcredit programs.

From the researches, we summarize and describe the variables in the model as Table 1: 


\begin{tabular}{|c|c|c|c|}
\hline Variables & Symbols & Calculation & Source \\
\hline Bank credit accessibility & Foac $(\mathrm{m} 8 \mathrm{c} 7)$ & Euqal to 1 in case of borrowing from the Social Policies Bank and AgriBank. & \\
\hline \multicolumn{4}{|l|}{ Personal characteristics } \\
\hline Age of household units & Age (m1ac5) & The age of household by years & $\begin{array}{l}\text { Mwangi and Sichei (2011), Dinh and Dong (2015), Nguyen and Pham } \\
\text { (2010), Vuong and Dang (2015) }\end{array}$ \\
\hline Sex of household head & Sex (m1ac2) & $\begin{array}{l}\text { The gender dummy receives } 1 \text { if the head of household is male. } \\
\text { The gender dummy receives } 0 \text { if the head of household is female. }\end{array}$ & $\begin{array}{l}\text { Ololade and Olagunju (2013), Dinh and Dong (2015), Vuong and Dang } \\
(2015)\end{array}$ \\
\hline Ethnicity & Eth (dantoc) & $\begin{array}{l}\text { Ethnic dumy variable equals to } 1 \text { if ethnic group is Kinh. } \\
\text { Ethnic dumy variable equals to } 0 \text { if it is another ethnic group. }\end{array}$ & Dinh and Dong (2015) \\
\hline Marital status & Sta (m1ac8) & $\begin{array}{l}\text { Marriage dummy variable equals to } 1 \text { if the households have couples. } \\
\text { Marriage dummy variable equals to } 0 \text { if other cases. }\end{array}$ & Ololade and Olagunju (2013) \\
\hline $\begin{array}{l}\text { Education status of head of } \\
\text { houshold }\end{array}$ & Edu (m2ac2a) & $\begin{array}{l}\text { Educational dummy variables equal to } 1 \text { if it has no qualification"; } 2 \text { if it is } \\
\text { primary; } 3 \text { if it is secondary school; } 4 \text { if it is high school; } 5 \text { if it is college; } 6 \text { if } \\
\text { it is university; } 7 \text { if others. }\end{array}$ & Assogba et al. (2017), Nguyen and Pham (2010), Dinh and Dong (2015) \\
\hline \multicolumn{4}{|c|}{ Demographic characteristics of Households } \\
\hline Household size & Size (tsnguoi) & Total members of households & Assogba et al. (2017), , Dinh and Dong (2015) \\
\hline Percentage of dependents & Dep & $\begin{array}{l}\text { The percentage of childern under } 16 \text { years old, the elder above } 60 \text { years old } \\
\text { in total households }\end{array}$ & Dinh and Dong (2015) \\
\hline \multicolumn{4}{|l|}{ Financial characteristics } \\
\hline Average income & thubq & $\begin{array}{l}\text { Narural logarit of annual household income from all sources } \\
\text { Unit: Thousands dong }\end{array}$ & Kiplimo et al. (2015) \\
\hline Individual Fin & $\begin{array}{l}\text { InF } \\
\left(\mathrm{m} 4 \mathrm{dc} 2 \_01 / \mathrm{m} 4 \mathrm{dc} 2 \_06\right)\end{array}$ & $\begin{array}{l}\text { Individual financing value equals } 1 \text { if the household receives sponsorships } \\
\text { from relatives, } O \text { if not }\end{array}$ & Dinh and Dong (2015) \\
\hline Saving & Sav $(\mathrm{m} 8 \mathrm{c} 3 \mathrm{~b})$ & $\begin{array}{l}\text { Dummy variables on saving receives } 1 \text { if households have saving account. } \\
\text { It receives } O \text { if houeholds does not have saving account }\end{array}$ & Dinh and Dong (2015) \\
\hline \multicolumn{4}{|l|}{ Credit characteristics } \\
\hline Borrowed time & LoanTime & $\begin{array}{l}\text { Time for unpaid loan } \\
\text { Unit: year. }\end{array}$ & \\
\hline Loan value & Loanv (m8c9) & $\begin{array}{l}\text { Loan value } \\
\text { Unit: thousands dong. }\end{array}$ & \\
\hline Amount to pay loan & Fee $(\mathrm{m} 8 \mathrm{c} 10)$ & $\begin{array}{l}\text { Amount to pay for loan } \\
\text { Unit: thousands dong }\end{array}$ & \\
\hline Official loan interest rate & LoanInterest & $\begin{array}{l}\text { Interest rate loan by month } \\
\text { Unit: \%. }\end{array}$ & Assogba et al. (2017), Ololade and Olagunju (2013), Bui and Truong (2014) \\
\hline $\begin{array}{l}\text { Loan purpose on loan } \\
\text { application }\end{array}$ & Taro (m8c13) & $\begin{array}{l}\text { Dummy loan purpose equals } 1 \\
\text { if the loan for agricultural activities includes "Other crops", "Livestock", } \\
\text { "Forestry", "Fishery", "Rice cultivation"; O if the loan for non-agricultural } \\
\text { activities includes "Education and Training", "Medical expenses", "Non- } \\
\text { agricultural activities", "Land purchase", "Purchase of other assets", }\end{array}$ & Tran and Huynh (2013) \\
\hline
\end{tabular}




\begin{tabular}{|c|c|c|c|}
\hline & & $\begin{array}{l}\text { "Repayment of other loans", "Construction / purchase of houses", "Other } \\
\text { operating costs" and "Other" }\end{array}$ & \\
\hline $\begin{array}{l}\text { The actual purpose is to use } \\
\text { the loan range }\end{array}$ & Tar $1(\operatorname{m8c} 14)$ & $\begin{array}{l}\text { Dummy variable for the actual purpose of using the loan equals } 1 \\
\text { if the loan for agricultural activities includes "Other crops", "Livestock", } \\
\text { "Forestry", "Fishery", "Rice cultivation"; O if the loan for non-agricultural } \\
\text { activities includes "Education and Training", "Medical expenses", "Non- } \\
\text { agricultural activities", "Land purchase", "Purchase of other assets", } \\
\text { "Repayment of other loans", "Construction / purchase of houses", "Other } \\
\text { operating costs" and "Others". }\end{array}$ & Dinh and Dong (2015) \\
\hline Mortgage property & $\mathrm{Col}(\mathrm{m} 8 \mathrm{c} 15)$ & Equals 1 if there is a mortgage; Equal 0 if there is no mortgage. & Diagne (1999) \\
\hline Amount owed & Unpay (m8c12) & $\begin{array}{l}\text { Total debt } \\
\text { Unit: thousands dong }\end{array}$ & \\
\hline \multicolumn{4}{|l|}{ Other factors } \\
\hline Natural shock & Nasock (m4b1b) & $\begin{array}{l}\text { Natural shock dummy variables such as } \\
\text { natural disasters and epidemics, equals } 1 \text { if receiving effects from these } \\
\text { factors and receive } O \text { if it does not have effects. }\end{array}$ & Dinh and Dong (2015) \\
\hline $\begin{array}{l}\text { Member of Farmers } \\
\text { Association }\end{array}$ & $\operatorname{Agrc}(\mathrm{m} 1 \mathrm{ac} 15 \mathrm{a})$ & $\begin{array}{l}\text { Recevie } 1 \text { if you are members of farmer's union, } 0 \text { if you are not mebers of } \\
\text { farmers' uninion. }\end{array}$ & Assogba et al. (2017) \\
\hline Member of Women's Union & Womec (m1ac15b) & Receive 1 if you are members of women's union, 0 if you are not members. & Assogba et al. (2017) \\
\hline Party member & Party (m1ac15c) & Equal 1 if they are party members, 0 they are not party members. & Assogba et al. (2017) \\
\hline $\begin{array}{l}\text { Member of Veterans } \\
\text { Association }\end{array}$ & Veterc (m1ac15d) & $\begin{array}{l}\text { Receive } 1 \text { if it belongs to Member of Veterans Association, } O \text { if it does not } \\
\text { belong to Member of Veterans Association }\end{array}$ & Assogba et al. (2017) \\
\hline
\end{tabular}




\section{Research Methods and Data \\ 3.1. Research Methods}

To measure factors affecting the bank credit accessibility of rural households in Vietnam, Heckman two-stage method (Heckman, 1979) was used in this research. In particular, the bank credit accessibility of rural households is assessed through two criteria: (i) the possibility to receive bank credit with the control group that are households cannot access bank credits; (ii) the total amount borrowed by the rural households.

The first stage of Heckman method is to use the probability unit model to estimate the possibility to receive loans of rural households. The specific model is as Equation 1:

$$
P=F(\alpha+\beta X)=\frac{1}{1+e^{-(\alpha+\beta X)}}
$$

To make an estimate, the model (1) is needed to convert to a linear form as Equation 2:

$$
\text { Foac }_{i}=\alpha+\beta_{i} X_{i}+\varepsilon_{i}
$$

In which, Foac is the possibility to receive bank credit of the $i^{\text {th }}$ household. Foac equals 1 if the household can receive a bank credit and equals $\mathrm{O}$ in the opposite case; $\mathrm{X}$ are control variables that may affect the possibility to receive bank credit of the household including personal characteristics (age, gender, ethnic group, marital status, educational status), demographic characteristics (household size, percentage of dependent persons), financial characteristics of the household (average income, personal funding, savings, unpaid loan value), member of associations (Farmers Associations, Women's Unions, householder as a Communist Party member, Veterans Association), natural shocks; $\boldsymbol{E}$ is interference.

The second stage in the Heckman two-stage model is to estimate the bank credit limits received by the households by the ordinary least square (OLS) method. The regression model is as Equation 3:

$$
\text { Loanv }_{i}=\alpha+\beta_{i} X_{i}+\varepsilon_{i}
$$

In which, Loanv is the total amount borrowed by the $\mathrm{i}^{\text {th }}$ household; $\mathrm{X}$ are control variables that can affect the loan value of the household including personal characteristics (age, gender, ethnic group, marital status, educational status of the householder), demographic characteristics (household size, percentage of dependent persons), financial characteristics of the household (average income, personal funding, savings, unpaid loan value, borrowing durations of unpaid loans), credit characteristics (official loan interest rate, loan term, total collateral value, with guarantor, amount payable for loan, purpose of loan as per the application for borrowing, actual use of loans, mortgage of assets), member of associations (Farmers Association, Women's Unions, householder as a Communist Party member, Veterans Association), natural shocks; $\boldsymbol{E}$ is interference.

\subsection{Research Data}

This research uses secondary data from dataset of Vietnam Household Living Standard Survey in 2014 and 2016 to eliminate the shock due to the global economic crisis in 2008-2009 making the estimate unsustainable. The survey scope of this dataset is 61 provinces and cities implemented by the General Statistics Office from 2002 to 2016 in which the surveyed subjects are households, members of households and communes/wards.

The survey applies the direct interview method through questionnaires in which the surveyors visit the householder and related members in the household. At the household level, some characteristics collected include demographic items, household income, household expenditure, educational level, heath status, employment status, assets and properties, participation in poverty and alleviation programs, etc. At the commune/ward level, some aspects collected are socio-economic infrastructure and economic situation.

\section{Research Results}

\subsection{Descriptive Statistics}

The statistical results showed that the average credit capital borrowed by each rural household was about VND 48 million in 2014 and VND 55 million in 2016. The largest loan values in 2014 and 2016 were respectively VND 1.25 billion and VND 1 billion. The average monthly interest rate was $0.87 \%$ and $0.70 \%$ in 2014 and 2016 , respectively. The average previous borrowing duration in 2014 was almost twice that in 2016. The amount payable for loan in 2016 was less than that in 2014. Average income per capita of the households in 2016 was improved in comparison to that in 2014, Table 2.

In general, the households continue to significantly depend on informal credit sources including Farmers 'Association, Veterans Association, Women's Unions, traders, especially friends, relatives, etc. Moreover, if the purposes of borrowing are divided by applications for borrowing and actual use of loans in agricultural and nonagricultural activities, no significant difference in the proportion between the two types of borrowing purposes appears. This implies that about $50 \%$ of rural households borrow for agriculture, the remaining about $50 \%$ borrow for education and training, medical examination and treatment, land purchase, repayment for other loans, house building/purchase. A notable point here is the actual use of loans for agricultural activities is even lower than the purpose of loans according to applications for borrowing. 
Table-2. Descriptive statistics results

\begin{tabular}{|c|c|c|c|c|c|c|c|c|c|}
\hline \multirow[t]{2}{*}{$\overline{\text { Variables }}$} & \multirow[t]{2}{*}{ Marked } & \multicolumn{2}{|c|}{ Average } & \multicolumn{2}{|c|}{ Standard deviation } & \multicolumn{2}{|c|}{ Lowest } & \multicolumn{2}{|c|}{ Highest } \\
\hline & & 2014 & 2016 & 2014 & 2016 & 2014 & 2016 & 2014 & 2016 \\
\hline Credit accessibility & Foac & 0.81 & 0.83 & 0.40 & 0.37 & $\mathrm{O}$ & $\mathrm{O}$ & 1 & 1 \\
\hline Average income & avgincome & 1855.15 & 2226.03 & 1674.02 & 2712.57 & 224 & 357 & 17159 & 57146 \\
\hline Total income & Income & 87723.37 & 99909.87 & 81902.95 & 89489.91 & 10447 & 10999 & 1029550 & 1371510 \\
\hline Householder's age & Age & 46.80 & 47.80 & 11.76 & 11.58 & 19 & 21 & 89 & 91 \\
\hline Householder's gender & Sex & 0.81 & 0.79 & 0.39 & 0.41 & $\mathrm{O}$ & $\mathrm{O}$ & 1 & 1 \\
\hline Ethnic group & Eth & 0.75 & 0.73 & 0.44 & 0.44 & $\mathrm{O}$ & $\mathrm{O}$ & 1 & 1 \\
\hline Marital status & Sta & 0.85 & 0.84 & 0.35 & 0.36 & $\mathrm{O}$ & $\mathrm{O}$ & 1 & 1 \\
\hline $\begin{array}{l}\text { Householder's education } \\
\text { status }\end{array}$ & Edu & 2.66 & 2.66 & 1.50 & 1.47 & 1 & 1 & 7 & 7 \\
\hline Household size & Size & 4.17 & 4.04 & 1.47 & 1.48 & 1 & 1 & 10 & 10 \\
\hline $\begin{array}{l}\text { Percentage of dependent } \\
\text { persons }\end{array}$ & Dep & 0.37 & 0.37 & 0.25 & 0.26 & $\mathrm{O}$ & $\mathrm{O}$ & 1 & 1 \\
\hline Personal funding & Inf & 0.84 & 0.85 & 0.37 & 0.36 & $\mathrm{O}$ & $\mathrm{O}$ & 1 & 1 \\
\hline Savings & Sav & 0.02 & 0.02 & 0.12 & 0.14 & $\mathrm{O}$ & $\mathrm{O}$ & 1 & 1 \\
\hline $\begin{array}{ll}\begin{array}{l}\text { Previous } \\
\text { duration }\end{array} & \text { borrowing } \\
\end{array}$ & Loantime & 4.26 & 2.75 & 2.14 & 2.65 & 2 & .25 & 17.58333 & 20.41667 \\
\hline Loan value & Loanv & 47664.28 & 55012.31 & 97139.68 & 99102.06 & 890 & 500 & 1250000 & 1000000 \\
\hline Amount loan payment & Fee & 34.78 & 33.70 & 250.65 & 222.19 & $\mathrm{O}$ & $\mathrm{O}$ & 5000 & 3000 \\
\hline $\begin{array}{l}\text { Official loan interest } \\
\text { rate }\end{array}$ & Loaninterest & 0.87 & 0.70 & 1.42 & 0.90 & $\mathrm{O}$ & $\mathrm{O}$ & 12.5 & 10 \\
\hline $\begin{array}{l}\begin{array}{l}\text { Purpose of loan as per } \\
\text { application }\end{array} \\
\text { borrowing } \\
\text { for }\end{array}$ & Taron & 0.54 & 0.51 & 0.50 & 0.50 & $\mathrm{O}$ & $\mathrm{O}$ & 1 & 1 \\
\hline Actual use of loan & Tar1n & 0.44 & 0.41 & 0.50 & 0.49 & $\mathrm{O}$ & 9 & 1 & 1 \\
\hline Mortgage of assets & $\mathrm{Col}$ & 0.35 & 0.38 & 0.48 & 0.49 & $\mathrm{O}$ & $\mathrm{O}$ & 1 & 1 \\
\hline Unpaid amount & Unpay & 46310.68 & 50707.68 & 99071.25 & 92548.86 & 890 & $\mathrm{O}$ & 1250000 & 1000000 \\
\hline Nature shock & Nasock & 0.84 & 0.84 & 0.37 & 0.37 & $\mathrm{O}$ & $\mathrm{O}$ & 1 & 1 \\
\hline $\begin{array}{l}\text { Member of Farmers } \\
\text { Association }\end{array}$ & Agrc & 0.45 & 0.44 & 0.50 & 0.50 & $\mathrm{O}$ & $\mathrm{O}$ & 1 & 1 \\
\hline $\begin{array}{l}\text { Member of Women's } \\
\text { Union }\end{array}$ & Womec & 0.11 & 0.11 & 0.32 & 0.32 & $\mathrm{O}$ & $\mathrm{O}$ & 1 & 1 \\
\hline Party member & Party & 0.07 & 0.07 & 0.25 & 0.26 & $\mathrm{O}$ & $\mathrm{O}$ & 1 & 1 \\
\hline $\begin{array}{l}\text { Member of Veterans } \\
\text { Association }\end{array}$ & Veterc & 0.10 & 0.09 & 0.31 & 0.28 & $\mathrm{O}$ & $\mathrm{O}$ & 1 & 1 \\
\hline
\end{tabular}

Source: Calculated by the author based on VHLSS 2014 and VHLSS 2016 dataset.

An important feature of households receiving loans is often that such household is a member a certain organization such as Farmer's Associations, Women's Unions, etc. According to statistics data, more than 38.63\% of households obtaining loans from bank credits are members of the Farmers Association. This rate is higher than the proportion of households in which there is a member joining in the Women's Unions, Farmers Associations, as a member of Party and Veterans Association in the sample Table 3.

Table-3. Participated characteristic of household association under credit access

\begin{tabular}{|c|c|c|c|c|}
\hline \multirow[t]{2}{*}{ Characteristic of household } & $\begin{array}{c}\text { Access to } \\
\text { credit bank }\end{array}$ & $\begin{array}{c}\text { Access to informal } \\
\text { credit }\end{array}$ & $\begin{array}{c}\text { Access to } \\
\text { credit bank }\end{array}$ & $\begin{array}{c}\text { Access to informal } \\
\text { credit }\end{array}$ \\
\hline & 2014 & 2014 & 2016 & 2016 \\
\hline \multicolumn{5}{|l|}{ Member of Farmers Association } \\
\hline Yes & $38.63 \%$ & $6.52 \%$ & $39.30 \%$ & $4.52 \%$ \\
\hline No & $42.14 \%$ & $12.71 \%$ & $44.15 \%$ & $12.04 \%$ \\
\hline \multicolumn{5}{|l|}{ Member of Women's Union } \\
\hline Yes & $8.19 \%$ & $3.01 \%$ & $9.20 \%$ & $2.17 \%$ \\
\hline No & $72.58 \%$ & $16.22 \%$ & $74.25 \%$ & $14.38 \%$ \\
\hline \multicolumn{5}{|l|}{ Party member } \\
\hline Yes & $6.02 \%$ & $0.84 \%$ & $6.52 \%$ & $0.50 \%$ \\
\hline No & $74.75 \%$ & $18.39 \%$ & $76.92 \%$ & $16.05 \%$ \\
\hline \multicolumn{5}{|l|}{ Member of Veterans Association } \\
\hline Yes & $8.36 \%$ & $2.01 \%$ & $7.36 \%$ & $1.17 \%$ \\
\hline No & $72.41 \%$ & $17.22 \%$ & $76.09 \%$ & $15.38 \%$ \\
\hline
\end{tabular}

Source: Calculated by the author based on VHLSS 9014 and VHLSS 2016 dataset

\subsection{Correlation Analysis}

The research analyzes experimental results on determinants of bank credit accessibility of rural households in Vietnam. Firstly, the author considers households with major loans obtained from bank credit institutions and informal credits, thereby analyzes which characteristics determine the bank credit accessibility. Then, the difference in the size of loans received by the households is analyzed.

Before selecting variables in the research model, the author uses the results from the correlation matrix to eliminate the multicollinearity among them. The results show that most correlation coefficients are less than 0.8 in all the models researched, except for the variable representing the unpaid loan value in Heckman two-stage model. Therefore, this variable is excluded from the research model 


\subsection{Regression Results}

In this research, the research samples are not selected in a random way, the use of regression techniques would thus give deviated parameter estimates. In order to analyze the types of credit households access and the impact of credit accessibility on household income, we control that, in fact, households accessing credits are self-selected ones. These households may have characteristics related to the fact that they also have credit loans. To control this deviation when estimating parameters using standard regression techniques, the research uses Heckman's sample selection model (Heckman, 1979). This model requires estimation to be done through two stages, also known as Heckman two-stage model. In particular, the first stage is to analyze the determinants of bank or informal credit accessibility of households using the Probit model. These determinants are controlled in the regression in the second stage to estimate household income by including the ratio of the probability density function to the inverse mills ratio from the Probit model in the first stage.

Table-4. Results of analysis of the first stage Heckman model on the ability of rural households to access bank credit.

\begin{tabular}{|c|c|c|c|}
\hline \multirow{2}{*}{ Variables } & \multirow{2}{*}{ Symbols } & 2014 & 2016 \\
\hline & & coefficient & coefficient \\
\hline Average income & avgincome & $\begin{array}{c}0.1924162^{*} \\
(0.1150844)\end{array}$ & $\begin{array}{c}-0.1830993^{*} \\
(0.1158562)\end{array}$ \\
\hline Householder's age & Age & $\begin{array}{l}0.0118241^{* *} \\
(0.0059941)\end{array}$ & $\begin{array}{l}0.0100962^{*} \\
(0.0062873)\end{array}$ \\
\hline Householder's gender & Sex & $\begin{array}{l}-0.2363856 \\
(0.2607638)\end{array}$ & $\begin{array}{c}0.056564 \\
(0.2404464)\end{array}$ \\
\hline Ethnicity & Eth & $\begin{array}{c}-0.4341966^{* * *} \\
(0.175618)\end{array}$ & $\begin{array}{l}-0.1341527 \\
(0.1721352)\end{array}$ \\
\hline Marital status & Sta & $\begin{array}{l}0.674162^{* * * *} \\
(0.2317677)\end{array}$ & $\begin{array}{c}0.2899067 \\
(0.2271619)\end{array}$ \\
\hline Education status of head of household & Edu & $\begin{array}{l}-0.0299758 \\
(0.0408896)\end{array}$ & $\begin{array}{l}-0.0072173 \\
(0.0451158)\end{array}$ \\
\hline Household size & Size & $\begin{array}{c}0.0489896 \\
(0.0484098)\end{array}$ & $\begin{array}{c}0.0612807 \\
(0.0490915)\end{array}$ \\
\hline Percentage of dependents & Dep & $\begin{array}{l}-0.2069048 \\
(0.2553241)\end{array}$ & $\begin{array}{l}-0.3183561 \\
(0.2645414)\end{array}$ \\
\hline Individual financing & Inf & $\begin{array}{c}-0.1362114 \\
(0.179475)\end{array}$ & $\begin{array}{l}-0.0630081 \\
(0.1870923)\end{array}$ \\
\hline Saving & Sav & $\begin{array}{c}0.1122132 \\
(0.5754466)\end{array}$ & $\begin{array}{c}0.0641152 \\
(0.4420232)\end{array}$ \\
\hline Unpaid amount & Unpay & $\begin{array}{c}-1.92 \mathrm{e}-06^{* * * *} \\
(6.83 \mathrm{e}-07)\end{array}$ & $\begin{array}{c}-1.24 \mathrm{e}-06^{* *} \\
(6.73 \mathrm{e}-07)\end{array}$ \\
\hline Natural shock & Nasock & $\begin{array}{c}0.1168149 \\
(0.16935)\end{array}$ & $\begin{array}{c}0.0348077 \\
(0.1721933)\end{array}$ \\
\hline Member of Farmers Association & Agrc & $\begin{array}{l}0.2877241^{* *} \\
(0.1342664)\end{array}$ & $\begin{array}{l}0.3890931^{* * * *} \\
(0.1434584)\end{array}$ \\
\hline Member of Women's Union & Womec & $\begin{array}{l}-0.1039865 \\
(0.2662187)\end{array}$ & $\begin{array}{c}0.1353885 \\
(0.2667266)\end{array}$ \\
\hline Party member & Party & $\begin{array}{c}0.2803205 \\
(0.3026963)\end{array}$ & $\begin{array}{c}0.610192^{*} \\
(0.3350208)\end{array}$ \\
\hline Member of Veterans Association & Veterc & $\begin{array}{l}-0.3000168 \\
(0.2240461)\end{array}$ & $\begin{array}{l}-0.1578418 \\
(0.2607071)\end{array}$ \\
\hline Constant & _Cons & $\begin{array}{c}-1.133473 \\
(0.9349581)\end{array}$ & $\begin{array}{c}1.489394 \\
(0.9891055)\end{array}$ \\
\hline
\end{tabular}

Source: Calculated by the author based on VHLSS 2014 and VHLSS 2016 dataset.

Among the factors that can affect the credit accessibility considered in the first stage of Heckman model, there are six factors that have significant and statistically significant effects on the bank credit capital accessibility of rural households. They include average income of the household, age of the householder, ethnic group, marital status, previous borrowing duration, member of Farmers Associations and Party member (Table 4).

Firstly, the average income of the household has a remarkably positive and statistically significant effect on the bank credit capital accessibility of households at $10 \%$. Households with a higher average annual income have higher accessibility to bank credit capital than to informal credit capital. This conclusion is similar to Tran and Huynh (2013), Bui and Truong (2014), Nguyen and Pham (2010), Vuong and Dang (2015), Mwangi and Sichei (2011) but contrary to Kiplimo et al. (2015).

Secondly, the estimation results show that age of the householder has a positive impact on the bank credit capital accessibility of households at significant rates of 5\% (2014) and 10\% (2016). This implies that the older the householder is, the higher the probability of accessing bank credit capital is. This finding is supported by Nguyen and Pham (2010), Vuong and Dang (2015) and Mwangi and Sichei (2011).

Thirdly, the bank credit accessibility is also increased for households classified in Kinh ethnic group. Data show that the ethnic group factor has a remarkably positive and statistically significant impact at $5 \%$ in 2014 , which is, however, not statistically significant in 2016. This is perfectly reasonable since Kinh people households often live in the delta so it is easy for them to access bank credit institutions. Meanwhile, households of other ethnic groups often live in remote areas with difficult transportation, so it is difficult for them to access bank credit institutions. Moreover, ethnic minority households face many difficulties in production, have low skills and educational levels, and are multi-child and backward families, which hence create many barriers to access to the formal capital. This conclusion contrasts with Development Economics Research Group (DERG).

Fourthly, the research results indicate that the marital status of the householder is an important factor 
significantly impacting on the bank credit accessibility of rural households at a statistically significant rate of $1 \%$ in 2014 which is, however, not significant in 2016. This means that a householder who is currently married has a higher accessibility to bank credit than to the informal credit. This finding is not supported by the Development Economics Research Group (DERG), Duy et al. (2012) as well as Ololade and Olagunju (2013).

Fifthly, the duration of unpaid loans also reduces the bank credit accessibility of rural households in Vietnam. This result has statistical significance rates of $1 \%(2014)$ and $5 \%$ (2016). This finding implies that the longer the debts owed to households are, the more decreasing their possibility to receive the formal loan capital is. This is an important finding that previous researches have not yet shown.

Finally, that households are currently members of Farmers Associations has an important meaning in the decisions to issue loans from bank credit institutions, which has a statistical significance rates of $5 \%$ and $10 \%$ in 2014 and 2016, respectively. For householders who are Party members, their reputation also has a positive effect on their bank credit accessibility in 2016. However, if the households are members of Women's Unions or Veterans Associations, there is no statistical significance regarding the impact on their bank credit accessibility. This result is consented by Assogba et al. (2017), Tran and Huynh (2013) and the Development Economics Research Group (DERG) when thinking that organizations and unions like the Farmers Associations play an important role in the credit accessibility of Vietnamese rural households in connection with agricultural, non-agricultural and investment loans.

Table 5 presents the estimation results of Heckman two-stage model on the possibility to receive loans of rural households in Vietnam. The results show that there are 18 factors that affect the value of loans received from bank credit institutions including average income of the household, age of the householder, gender of the householder, ethnic group, marital status, educational status of the householder, household size, percentage of dependent persons, personal funding, savings, purpose of loan according to application for borrowing, mortgage of assets, natural shock, previous borrowing duration and members of Associations and Unions.

Table-5. Results of Heckman model analysis of the second step on the ability of rural households to access bank credit.

\begin{tabular}{|c|c|c|c|}
\hline \multirow{2}{*}{ Variables } & \multirow{2}{*}{ Symbols } & 2014 & \multirow{2}{*}{$\begin{array}{c}2016 \\
\text { coeficient }\end{array}$} \\
\hline & & coeficient & \\
\hline Average income & avgincome & $\begin{array}{l}73649.6^{* * * *} \\
(2601.12) \\
\end{array}$ & $\begin{array}{c}-67017.78^{* * * *} \\
(4726.173)\end{array}$ \\
\hline Householder's age & Age & $\begin{array}{c}4132.494^{* * * *} \\
(165.016)\end{array}$ & $\begin{array}{c}4118.629^{* * * *} \\
(220.0773)\end{array}$ \\
\hline Householder's gender & Sex & $\begin{array}{c}-87452.24^{* * * *} \\
(6413.622)\end{array}$ & $\begin{array}{c}38572.18^{* * * *} \\
(7154.788)\end{array}$ \\
\hline Ethnicity & Eth & $\begin{array}{c}-139839.4^{* * * * *} \\
(4766.728) \\
\end{array}$ & $\begin{array}{c}-50314.83^{* * * *} \\
(4712.804) \\
\end{array}$ \\
\hline Marital status & Sta & $\begin{array}{c}273940.4^{* * * *} \\
(8523.094)\end{array}$ & $\begin{array}{c}134770.6^{* * * *} \\
(7654.039)\end{array}$ \\
\hline Education status of head of household & Edu & $\begin{array}{c}-9616.384^{* * * *} \\
(986.8537) \\
\end{array}$ & $\begin{array}{c}568.6621 \\
(1208.606) \\
\end{array}$ \\
\hline Household size & Size & $\begin{array}{l}18312.25^{* * * *} \\
(1049.948)\end{array}$ & $\begin{array}{c}27264.61^{* * * *} \\
(1477.458)\end{array}$ \\
\hline Percentage of dependents & Dep & $\begin{array}{c}-78477.19^{* * * *} \\
(6239.476) \\
\end{array}$ & $\begin{array}{c}-132654.2^{* * * *} \\
(8557.581) \\
\end{array}$ \\
\hline Individual financing & Inf & $\begin{array}{c}-43027.84^{* * * *} \\
(3818.201)\end{array}$ & $\begin{array}{c}-17069.21^{* * * *} \\
(4940.635)\end{array}$ \\
\hline Savings & Sav & $\begin{array}{l}48638.26^{* * *} \\
(10767.17)\end{array}$ & $\begin{array}{c}55074.53^{* * * *} \\
(12755.77)\end{array}$ \\
\hline Borrowed time & Loantime & $\begin{array}{l}-772.9602 \\
(682.6477)\end{array}$ & $\begin{array}{l}-1178.365^{*} \\
(680.6268)\end{array}$ \\
\hline Fee of loan & Fee & $\begin{array}{c}7.022414 \\
(5.063817)\end{array}$ & $\begin{array}{c}9.431843 \\
(7.350401)\end{array}$ \\
\hline Loan interest & Loaninterest & $\begin{array}{c}16.54856 \\
(954.1035)\end{array}$ & $\begin{array}{c}590.087 \\
(2238.083)\end{array}$ \\
\hline Purpose of loan in the application form & Taron & $\begin{array}{c}-12535.81^{* *} \\
(4870.354) \\
\end{array}$ & $\begin{array}{l}-9727.456^{*} \\
(5875.016) \\
\end{array}$ \\
\hline The actual purpose of loan & Tar1n & $\begin{array}{c}6229.27 \\
(4800.941) \\
\end{array}$ & $\begin{array}{l}-2026.826 \\
(5765.248) \\
\end{array}$ \\
\hline Collateral & $\mathrm{Col}$ & $\begin{array}{l}15481.43^{* * * *} \\
(3151.804) \\
\end{array}$ & $\begin{array}{l}26878.8^{* * * * *} \\
(4084.574)\end{array}$ \\
\hline Natural shock & Nasock & $\begin{array}{l}51087.76^{* * * *} \\
(4355.186)\end{array}$ & $\begin{array}{c}23880.68^{* * * *} \\
(5294.871)\end{array}$ \\
\hline Member of Farmers Association & Agrc & $\begin{array}{l}102098.6^{* * * *} \\
(3860.518)\end{array}$ & $\begin{array}{c}159453.7^{* * * *} \\
(6395.516)\end{array}$ \\
\hline Member of Women's Union & Womec & $\begin{array}{c}-47029.69^{\text {****** }} \\
(6761.327) \\
\end{array}$ & $\begin{array}{c}66861.14^{* * * *} \\
(8245.986) \\
\end{array}$ \\
\hline Party member & Party & $\begin{array}{c}86252.55^{* * * *} \\
(6212.679) \\
\end{array}$ & $\begin{array}{c}203678.5^{* * * *} \\
(10141.56)\end{array}$ \\
\hline Member of Veterans Association & Veterc & $\begin{array}{c}-115005.1^{* * * * *} \\
(5578.39)\end{array}$ & $\begin{array}{c}-67691.25^{* * * * *} \\
(7140.371) \\
\end{array}$ \\
\hline & Lambda & $\begin{array}{c}962010.9^{* * * *} \\
(23292.64)\end{array}$ & $\begin{array}{l}1201355^{* * * *} \\
(38324.22) \\
\end{array}$ \\
\hline Constant & _Cons & $\begin{array}{c}-1125626^{* * * *} \\
(30100.51)\end{array}$ & $\begin{array}{l}-261218.6 \\
(27134.05)\end{array}$ \\
\hline
\end{tabular}

$\%, 5 \%$ and $1 \%$ respectively.

Source: Calculated by the author based on VHLSS 2014 and VHLSS 2016 dataset. 
Firstly, the average incomes of households have a remarkably positive and statistically significant effect on the value of the loans they receive from the bank credit institutions at 10\%. Households with higher average annual incomes have higher accessibility to bank credit capital than to informal credit capital. This conclusion is similar to Nguyen and Pham (2010), Tran and Huynh (2013), Bui and Truong (2014), Vuong and Dang (2015), Mwangi and Sichei (2011) but contrary to the Development Economics Research Group (DERG).

Second, the estimation results explain that ages of the householders have a positive impact on the value of the loans they receive from bank credit institutions at a significant rate of $5 \%$. This implies that the older the householder is, the higher the probability of receiving bank credit capital than informal credit capital is. This finding is supported by Nguyen and Pham (2010), Vuong and Dang (2015) and Mwangi and Sichei (2011).

Thirdly, the value of loans received from bank credit institutions is also increased for households of Kinh ethnic group. Evidence shows that Kinh people households are often more favorable in getting more loans from bank credit institutions. This conclusion contrasts with the Development Economics Research Group (DERG) when considering that the difference among ethnic group-related characteristics of households is not a barrier to credit accessibility.

Fourthly, the findings in Table 5 also indicate that marital status of the householders is a key factor that has a significant effect on the value of the loans received from the bank credit institutions by rural households at a statistically significant rate of $1 \%$. This implies that the householders who are currently married have higher possibility to receive loans from bank credit institutions than from informal credits. This finding is also not similar to the Development Economics Research Group (DERG), Duy et al. (2012) as well as Ololade and Olagunju (2013).

Fifthly, the duration of unpaid loans also reduces the value of loans received from bank credit institutions by rural households at a statistically significant rate of $1 \%$. This finding implies that the longer the debts owed to households are, the more decreasing the value of loans received from bank credit institutions is. This is in line with the credit rating criteria of Vietnamese banks.

Sixthly, that households are currently members of associations and unions including Farmers Associations, Women's Unions, householders as a Party member and Veterans Associations has a positive effect on the value of loans received from bank credit institutions by rural households. This shows that received loans are tended to higher thanks to participation in social activities and prestige of the householders. This result is agreed by Assogba et al. (2017), Tran and Huynh (2013) and the Development Economics Research Group (DERG).

Finally, other factors significantly affecting the value of loans received from bank credit institutions include gender of the householder, educational status of the householder, household size, percentage of dependent persons, personal funding, savings, purpose of loan according to application for borrowing, mortgage of assets and natural shock.

In summary, based on the results obtained from the Heckman two-stage model, the research shows factors including average income of household, age of householder, ethnic group, marital status, duration of unpaid loans and member of Farmers Association, the householder as a Party member have a significant influence on the bank credit accessibility. In contrast, the evidence have not yet shown the factors including gender of householder, educational status of householder, household size, percentage of dependent persons, personal funding, savings, members of Women's Union or Veterans Association impact on the bank credit accessibility.

\section{Conclusion and Recommendation}

\subsection{Rural Households}

Firstly, improve credit accessibility of rural households in Vietnam. In fact, credit information accessibility of rural households is limited. The main reason is that education level, resident's living standards, access to information and equal rights are still low compared to urban areas. Therefore, communication channels need to be disseminated widely to improve bank credit accessibility for rural households. Local authorities at all levels need to establish a department / committee equipped with sufficient criteria on facilities and resources with intensive skills to update credit information for local people. The provision of information to the people must be diversified in different forms such as local radio stations listing at offices, and distributing leaflets together with other administrative procedures.

Secondly, encourage households to join mass organizations. Most households in rural areas face many barriers in accessing to credit, such as low education levels, low income, high number of dependents, limited time for social activities. due to livelihood activities, geographical distance, ... affecting credit accessiblity. Participation in local mass organizations such as Women's Union, Farmers 'Association, Veterans' Association, etc. will help people have more conditions in sharing information, creating close relationships among households. Mass organizations are also channels to connect with banks, state agencies, etc. thus updating the information fully and promptly on the credit market.

Thirdly, support households to complete land ownership certificates. Most rural households have the biggest asset is land. However, the number of rural households granted land ownership certificates is still low compared to urban households. Therefore, the Government should have policies to encourage households, especially in rural areas, to obtain land ownership certificates, creating favorable conditions for households to access credit.

\subsection{Banks}

Firstly, improve lending process and procedures for rural households. In fact, rural households borrow directly with a complicated loan process at banks. Therefore, to improve households' access to bank credit, banks need to simplify procedures and streamline lending processes for rural households so they can access to credit easily and fastly. On the other hand, banks need to understand the production activities of each of their customers, especially agriculture - forestry - fishery production because each type of production will affect the process of loan. Therefore, expand credit and loan conditions accordingly, facilitate borrowers to access credit and pay interest. Moreover, although collateral is one of the lending conditions, banks should not see collateral as a decisive factor in lending.

Secondly, deploy lending to production households through mass organizations. Banks need to cooperate with mass organizations in lending activities because of the reduction of human resource costs that are often lacking in 
rural areas to disburse and monitor. Furthermore, mass organizations hold get information about households and can provide more information to consult banks in loan profile reviews. Lending through mass organizations also contributed to improving the knowledge and skills of bankers in taking care of borrowers, closely observing the status of production and business of farmers as well as propagating policies, credit information for farmers.

Thirdly, strengthen the promotion of images and brand of banks. In order to improve access to bank credit, banks need to promote communication activities for rural households.

\subsection{Government}

Firstly, promoting the implementation of credit policies for rural area development. The government needs to continue to adjust the loan structure of commercial banks to prioritize medium and long-term loans.

Secondly, complete procedures for granting land ownership certificates. The Government implement a longterm stable allocation of land for rural households, and accelerate the process of granting land ownership certificates so that farmers could have enough assets to secure bank mortgages. This is one of the main barriers to access bank credit of rural households today.

Thirdly, there are sanctions to limit the forms of access to black credit, high-interest loans.

\section{References}

Assogba, P.N., S.E.H. Kokoye, R.N. Yegbemey, J.A. Djenontin, Z. Tassou, J. Pardoe and J.A. Yabi, 2017. Determinants of credit access by smallholder farmers in North-East Benin. Journal of Development and Agricultural Economics, 9(8): $210-216$.

Bui, V.T. and T.P.T. Truong, 2014. Analysis of the formal credit capital access: The case of shrimp farmers in Tra Vinh province. Science Journal of Can Tho University, 32: 1-6.

Claessens, S. and E. Feijen, 2007. Financial sector development and the millennium development goals (No. 89). World Bank Publications.

Diagne, A., 1999. Determinants of household access to and participation in formal and informal credit markets in Malawi. FCND Discussion Paper No. 67.

Dinh, P.H. and D. Dong, 2015. The impact of formal credit on household incomes in Vietnam. Journal of Economic Development, 26(2): 6582.

Duy, V.Q., M. D’Haese, J. Lemba and L. D’Haese, 2012. Determinants of household access to formal credit in the rural areas of the Mekong Delta, Vietnam. African and Asian studies, 1 1(3): 261-287.Available at: https://doi.org/10.1 163/15692108-12341234.

Economic and Development Group, 2010. The availability and effectiveness of rural credit in Vietnam: Investigation evidence Access to household resources in Vietnam 2006-2008-2010. Copenhagen University (Uoc) - Agriculture and Rural Development Program (ARD).

Heckman, J.J., 1979. Sample selection bias as a specification error. Econometrica: Journal of the Econometric Society, 47(1): 153161.Available at: https://doi.org/10.2307/1912352.

Kiplimo, J.C., E. Ngenoh, W. Koech and J.K. Bett, 2015. Determinants of access to credit financial services by smallholder farmers in Kenya. Journal of Development and Agricultural Economics, 7(9): 303-313.

Mwangi, I.W. and M.M. Sichei, 2011. Determinants of access to credit by individuals in Kenya: A comparative analysis of the Kenya national finaccess surveys of 2006 and 2009. European Journal of Business and Management, 3(3): 206-227.

Nguyen, C.H., 2007. Access to credit and borrowing behaviour of rural households in a Transition Economy. [Accessed August, 23, 2013].

Nguyen, Q.O. and T.M.D. Pham, 2010. The ability of accessing formal credit of farmers: A case study in suburban areas of Hanoi. Journal of Science and Development, 8(1): 170-177.

Nguyen, V.V.A., L.T. Hieu, N.T. Bup and N.T. An, 2016. Ability of accessing formal credit of tiger shrimp farmers in Cau Ngang district, Tra Vinh. Journal of Economics and Forecasting, 2: 44-46.

Ololade, R.A. and F.I. Olagunju, 2013. Determinants of access to credit among rural farmers in Oyo State, Nigeria. Global Journal of Science Frontier Research Agriculture and Veterinary Sciences, 13(2): 16-22.

Phan, D.K., 2013. Factors affecting access to formal and informal credit for farm households in the Mekong Delta. Science Journal of Can Tho University, 28: 38-53.

Rajan, R.G. and L. Zingales, 2003. The great reversals: The politics of financial development in the twentieth century. Journal of Financial Economics, 69(1): 5-50.Available at: https://doi.org/10.1016/s0304-405x(03)00125-9.

Roodman, D., 2009. CMP: Stata module to implement conditional (recursive) mixed process estimator. Statistical Software Components S456882, Boston College Department of Economics.

Stiglitz, J.E. and A. Weiss, 1981. Credit rationing in markets with imperfect information. The American Economic Review, $71(3)$ : 393-410.

Tran, A.K. and T.T. Huynh, 2013. Factors affecting the access to formal credit by households in An Giang province. Science Journal of Can Tho University, 27: 17-24.

Vuong, Q.D. and H.T. Dang, 2015. Analysis of factors affecting pig farmers' ability to access official credit in O Mon and Can Tho districts. Science Journal of Can Tho University, 36: 42-51. 